\title{
Kesantunan Berbahasa di Era Digital: Tinjauan Analisis Moral pada Komentar Berita Sepakbola di Akun Instagram@Pengamatsepakbola
}

Purwati

Universitas Pendidikan Indonesia

Indra Gunawan

IAIN Syekh Nurjati Cirebon purwatipurwa7@gmail.com

indra16gun@syekhnurjati.ac.id

- Received: 28.03.2019 • Accepted:02.04.2019 • Published online: 07.05.2019

Abstract: Social media is a new space for the public to interact in the digital era. This crowded means of interaction raises new problems in social relations that is the number of netizens who use abusive language in comments. As a result, social media becomes a tool to insult people, fight and spread hatred. Therefore, this study has the aim to describe the use of impolite language of netizens in the social media comment column and the factors that influence it. This study uses a qualitative descriptive approach, note taking techniques, theory triangulation, and analysis techniques based on a moral's point of view. The subject is netizens, while the object is politeness in language on social media. The results of this study are: a) netizens' language in commenting is categorized as impolite because it is contrary to the maxim of wisdom, generosity, appreciation, simplicity, consensus, and sympathy; $b$ ) factors that influence netizens in commenting are moral knowledge, recognized needs, mental readiness to accept new public spaces, cyberspace character, equality and a sense of friendship. Based on this research, it is needed material for digital society in using social media.

Keywords: politeness language, netizens, social media, comments 


\section{Pendahuluan}

Bahasa pada prinsipnya merupakan alat untuk berkomunikasi dan menunjukkan identitas masyarakat pengguna bahasa. Bahasa merupakan sarana penting untuk berkomunikasi antar manusia. Bahasa sebagai alat utama dalam berkomunikasi memiliki daya ekspresi dan informatif yang penting. Bahasa sangat dibutuhkan oleh manusia. Alasannya, bahasa bisa membuat manusia dapat memenuhi kebutuhan mereka dengan cara berkomunikasi antara satu dengan lainnya (Supratman, 2017). Sebagai anggota masyarakat yang aktif dalam kehidupan sehari-hari, manusia sangat bergantung pada penggunaan bahasa. Hal tersebut sesuai dengan pernyataan bahwa, "di mana ada masyarakat, di situ ada penggunaan bahasa". Dengan kata lain, di mana aktivitas terjadi, di situ aktivitas berbahasa terjadi pula (Sudaryanto, 1992).

Begitu tingginya kedudukan bahasa di dunia ini, sehingga para ahli mengatakan bahwa bahasalah yang membedakan manusia dengan makhluk lain (Pantu \& Luneto, 2017). Manusia memanfaatkan bahasa sebagai salah satu sarana untuk mengungkapkan pendapat, pikiran, dan ide. Hal tersebut menunjukan bahwa pentingnya bahasa dalam komunikasi dan interaksi antar manusia, sehingga manusia sadar bahwa mereka adalah makhluk yang membutuhkan bahasa untuk berkomunikasi dan bersosialisasi (Dari, Chandra, \& Sugiyati, 2017).

Dalam usaha untuk mengungkapkan diri mereka, sudah semestinya orang-orang tidak hanya menghasilkan tuturan yang mengandung kata-kata dan struktur-struktur gramatikal saja, tetapi mereka juga harus memperhatikan tindakan-tindakan kebermoralan melalui tuturan-tuturan bahasa tersebut yang termanifestasikan dalam kesantunan berbahasa (Yule, 2006). Kesantunan berbahasa perlu diperhatikan ketika berkomunikasi dengan orang lain agar tidak terjadi perpecahan ataupun kesalahpahaman (Dari et al., 2017). Perilaku bertutur dikatakan santun apabila seorang penutur menggunakan tata bahasa dengan memperhatikan etika bahasanya terhadap mitra tutur (Sauri, 2017). Etika berbahasa itu sendiri erat 
kaitannya dengan norma-norma sosial yang berlaku di dalam masyarakat. Etika berbahasa ini antara lain akan mengatur apa yang harus dikatakan pada waktu dan keadaan tertentu dan ragam bahasa apa yang wajib digunakan dalam situasi sosio-linguistik (Dari et al., 2017).

Kesantunan bahasa merujuk kepada nilai-nilai kesopanan, melibatkan tuturan yang halus dan indah serta sikap yang memancarkan budi pekerti mulia. Penutur yang menggunakan strategi kesantunan dalam tuturan mereka akan menggunakan bahasa yang halus. Kata-kata yang diucapkan tidak mempunyai maksud sindiran atau ejekan, sebaliknya kata-kata yang diucapkan mengandung unsur kejujuran, dan tidak menyinggung perasaan orang lain yang mendengarnya (Sauri, 2017). Kesantunan berbahasa dapat didefinisikan sebagai suatu sistem relasi interpersonal yang dirancang untuk memfasilitasi interaksi dengan cara meminimalkan potensi konflik yang secara alami terdapat dalam interaksi antar individu. Berbagai temuan empiris maupun kajian teoritis menunjukkan bahwa kesantunan berbahasa digunakan sebagai sarana untuk mempertahankan keseimbangan sosial dan sekaligus menjadi dukungan interpersonal dalam rangka mencegah konfrontasi (Lakoff, dalam Kuntarto, 2016) .

Perkembangan teknologi informasi dan komunikasi yang semakin pesat menunjukkan bahwa masyarakat semakin canggih dalam memanfaatkan produk-produk teknologi, termasuk dalam memanfaatkan media sosial sebagai alat untuk mendapatkan informasi dan berkomunikasi. Pemanfaatan media sosial yang seakan tanpa batas memberikan pola ketergantungan yang tinggi dan memberikan dampak positif dan negatif bagi penggunanya, misalnya sering kali ditemui di situs jejaring sosial yang salah satunya adalah Instagram (Inderasari, Achsani, \& Lestari, 2019). Melalui jejaring sosial Instagram, pengguna jejaring sosial yang biasa disebut dengan istilah netizen dapat dengan mudah mengomentari sebuah informasi yang diunggah oleh suatu akun di instagram. 
Kehadiran media sosial, khususnya instagram, membawa dampak tersendiri bagi kehidupan bermasyarakat. Misalnya memudahkan manusia untuk saling berkomunikasi dalam jarak jauh secara cepat. Dengan menyebarluasnya suatu jaringan, maka manusia pun merasa lebih mudah untuk saling berkomunikasi di mana saja dan dengan siapa saja. Namun tidak dapat dipungkiri dampak yang ditimbulkan dari adanya media sosial. Berbagai dampak negatif sering muncul, seperti ujaran kebencian (hate speech) ataupun bullying.

Nurrachmi \& Ririn (2018) mengungkapkan bahwa beberapa perilaku yang sering dilakukan oleh netizen seperti memaki, mengucapkan kata kotor, hingga merendahkan diri lawan bicara. Hal ini dikarenakan oleh para netizen atau pengguna internet yang kurang bijak dalam menggunakannya (Aziz, 2018). Sudah banyak bukti yang menunjukkan bahwa dewasa ini banyak perpecahan yang diakibatkan dari penggunaan media sosial yang tidak bijak. Misalnya, perpecahan antara kubu suporter sepakbola yang diawali dari percakapan di media sosial instagram. Oleh sebab itu, sisi kesantunan dalam berbahasa harus dijunjung tinggi agar di antara para penutur tidak terjadi kesalahpahaman yang dapat menimbulkan perselisihan (Inderasari, Achsani, \& Lestari, 2019).

Thomas Lickona mengungkapkan bahwa hubungan antara kualitas karakter dan kemajuan bangsa amat erat. Bangsa yang maju ditandai dengan kualitas karakter masyarakatnya yang baik. Lebih lanjut, ada sepuluh tanda-tanda zaman yang harus diwaspadai karena jika tanda-tanda itu sudah ada berarti ada sebuah indikasi yang menjukkan bahwa bangsa sedang menuju jurang kehancuran, dan dari ke sepuluh tanda-tanda zaman yang harus diwaspadai, sisi bahasa termasuk ke dalam sepuluh tanda tersebut, yaitu penggunaan bahasa dan kata-kata yang kian memburuk (Lickona, 1997).

Berdasarkan latar belakang di atas, penelitian ini bertujuan untuk mendeskripsikan penggunaan bahasa-bahasa yang tidak santun pada kolom komentar akun instagram @pengamatsepakbola dalam bermedia sosial serta faktor-faktor yang mempengaruhinya. Penelitian ini menggunakan metode kualitatif dengan pendekatan 
deskriptif. Sumber data penelitian ini berfokus pada komentarkomentar pengguna media sosial (netizen) di akun instagram @pengamatsepakbola yang biasa memposting berita tentang sepakbola. Diharapkan dengan adanya tulisan ini pembaca dapat menegakkan prinsip-prinsip kesantunan berbahasa sehingga para penutur mampu menggunakan bahasa dengan santun, baik di dunia maya maupun dunia nyata. Karena tidak dapat dipungkiri bahwa pada esensinya bahasa atau kata-kata adalah alat berpikir bagi manusia membangun komunikasi, relasi dan konstruksi social (Hendriani, dalam Gunawan, 2018).

\section{Metode}

Metode penelitian ini menggunakan pendekatan deskriptif kualitatif, hal ini dikarenakan bentuk data yang disajikan dalam penelitian ini berbentuk tulisan ujaran (komentar) dari para netizen yang terdapat dalam akun instragram @pengamatsepakbola. Teknik pengumpulan data dalam penelitian ini menggunakan teknik catat, yaitu dengan mencatat setiap komentar netizen dalam akun instagram @ pengamatsepakbola. Bugi (dalam Inderasari, Achsani, \& Lestari, 2019) menyatakan bahwa penggunaan teknik interaktif dilakukan dengan cara saling berkesinambungan antara pengumpulan observasi, data, analisis data, dan penyajian data. Peneliti melakukan pengamatan terhadap komentar netizen dalam suatu unggahan di akun @pengamatsepakbola. Langkah selanjutnya yaitu klasifikasi data, analisis data berdasarkan sudut pandang moral, dan penyajian data. Teknik yang digunakan dalam memvalidasi data adalah teknik triangulasi teori.

\section{Hasil dan Pembahasan}

\section{a. Analisis Data}

Kajian ini mengambil sampel satu video yang diunggah akun instagram @pengamatsepakbola tanggal 19 Oktober 2018. Video tersebut berisi insiden yang menimpa salah satu pemain Borneo FC yaitu AR saat mengikuti pertandingan sepak bola. Admin akun tadi menjelaskan bahwa AR melakukan pelanggaran lebih dari satu kali 
dan wasit bernama RR tidak memberi kartu kuning terhadap aksi pelanggaran tersebut. Insiden pelanggaran dan keputusan wasit ini menimbulkan beragam komentar netizen.

Di bawah ini adalah hasil analisis terhadap komentar para netizen atas berita AR tadi. Analisis dilakukan dengan menggunakan prinsip kesantunan berbahasa Leech (dalam Rahardi, 2005) yang meliputi maksim kebijaksanaan, kedermawanan, penghargaan, kesederhanaan, pemufakatan, dan kesimpatisan.

1) Maksim Kebijaksanaan

\section{Tabel 1}

Komentar Netizen I

\section{Netizen}

Sampel 1

Sampel 2

Sampel 3

\section{Isi Komentar}

Wasit sogokan ya gitulah..

anjing ni wasit, buta matanya

Wasit udah dikasi duit biar ga keluar kartu kuning dan kartu merahnya

Sebagaimana isi komentar yang tertera di tabel ini, keputusan wasit untuk tidak memberi sanksi terhadap AR direspon netizen dengan cara mengatakan "sogokan", "buta matanya", dan "dikasi duit". Ketiga komentar ini mengandung klaim bahwa wasit sudah disuap uang oleh orang yang mempunyai kepentingan dalam mengatur pertandingan sepak bola. Selain itu, terdapat klaim bahwa wasit memiliki kecacatan fisik di bagian mata (buta). Klaim-klaim seperti ini merugikan wasit sehingga bentuk komentar tersebut tidak sesuai dengan maksim kebijaksanaan.

2) Maksim Kedermawanan

\section{Tabel 2}

Komentar Netizen II

\section{Netizen Isi Komentar}

Sampel 4 Musim depan pake wasit2 asing yg benar2 berkwalitas aja, biar wasit kita ada rasa malu \& introspeksi diri,,,

Sampel 5 Bunuh wasitnya 
Sampel 6 Jangan dipake lagi wasit kaya gitu mah, suruh jadi wasit tarkam aja

Komentar netizen pada sampel 4, 5, dan 6 tidak sesuai dengan maksim kedermawanan. Alasannya, komentar ini manmpilkan kesan bahwa: 1) wasit lokal tidak memiliki kemampuan; 2) wasit asing lebih bagus dibandingkan wasit lokal; 3) menyuruh wasit lokal untuk pindah tempat ke pertandingan yang levelnya lebih rendah dari pertandingan sebelumnya; dan 4) saran untuk membunuh wasit RR. Kesan-kesan seperti ini dapat merugikan wasit dari segi masa depan pekerjaan dan jiwanya.

3) Maksim Penghargaan

Tabel 3

Komentar Netizen III

\begin{tabular}{cc} 
Netizen & Isi Komentar \\
\hline Sampel 7 & Wasit anjing \\
Sampel 8 & Wasit tolol \\
Sampel 9 & Wasit gila \\
\hline
\end{tabular}

Netizen sampel 7, 8, dan 9 mengandung cacian dan merendahkan harga diri wasit. Sebutan "anjing" terhadap wasit memiliki arti bahwa dirinya sebagai seorang manusia disamakan dengan hewan yang derajatnya di bawah manusia. Kata "tolol" dan "gila" memberi kesan bahwa wasit memiliki kemampuan rendah dan gangguan jiwa. Dengan demikian, ketiga komentar ini dinilai tidak santun dan bertentangan dengan maksim penghargaan.

4) Maksim Kesederhanaan

\section{Tabel 4}

Komentar Netizen IV

Netizen Isi Komentar

Sampel 10 Saya melihat wasit di liga gojek ini terlalu mahal utk kartu kuning apalagi kartu merah. Coba deh, lht liga inggris, wasit seperti tegas, lugas, ganjaran sesuai 
pelanggaran.

Komentar yang diungkapkan netizen sampel 10 tidak sesuai dengan maksim kesederhanaan. Kata "terlalu mahal" ketika memberi sanksi dan kata "coba deh" dalam melihat wasit liga Inggris memberi kesan bahwa netizen membanding-bandingkan wasit dengan cara memuji wasit liga Inggris sambil menjatuhkan wasit liga Indonesia.

5) Maksim Pemufakatan

\section{Tabel 5}

\section{Komentar Netizen V}

\section{Netizen Isi Komentar}

Sampel 11A : "Kalo Persib udah habis ini di sorot, kena sanksi 11 pasti

11B: "Dikit ${ }^{2}$ bawa persib.."

11C: "dia baper kali (ิ)"

Sampel 12A : "Pemain persib main kasar. Kaga lu repost min 12 @pengamatsepakbola. Adminya $100 \%$ bobotoh..(ㅇ)(ㅇ)="

12B : "permain persija pun kasar"

Keterangan: Pada sampel 11, simbol "11A", "11B", dan "11C" memiliki arti netizen sampel 11 poin " $A$ ", " $B$ ", dan " $C$ ". Pola penggunaan simbol ini sesuai juga dengan sampel 12 dan 13.

Pada sampel 11, netizen menanggapi unggahan video tentang pemain Borneo FC yang tidak disanksi meskipun melakukan

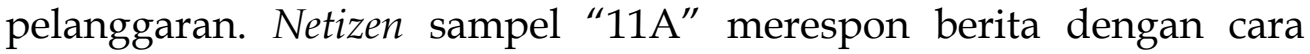
membahas perbedaan perlakuan wasit terhadap pemain Persib jika melakukan pelanggaran. Netizen sampel "11B" dan "11C" merespon netizen "11A" dengan cara memberi komentar yang terkesan tidak mendukung komentar netizen " $11 \mathrm{~A}^{\prime}$ ini.

Netizen sampel "12A" merespon unggahan admin dengan cara membahas pelanggaran yang dilakukan pemain Persib dan mengklaim admin sebagai pendukung klub tersebut. Komentar ini direspon oleh netizen sampel "12B" dengan cara membahas perilaku 
kasar pemain Persija. Komentarnya mendeskripsikan bahwa netizen ini tidak mendukung komentar "12A".

Berdasarkan penjelasan sampel netizen 11 dan 12, para netizen yang termasuk ke dalam kelompok sampel tadi tidak memiliki kesantunan berbahasa karena tidak sesuai dengan maksim pemufakatan. Tidak terjadi kecocokan antara komentar admin dan netizen maupun komentar antar netizen.

6) Maksim Kesimpatisan

\section{Tabel 6}

Komentar Netizen VI

\section{Netizen}

Isi Komentar

Sampel 13 Wasit buta 7turunan...amin

Sampel 14 Gw doain tuh wasit impotensi smpe stress hingga akhirnya bunuh diri.

Sebagaimana yang tergambar pada isi komentar di sampelsampel sebelumnya, wasit RR banyak memperoleh kritikan dan hinaan dari netizen atas keputusannya yang tidak memberi sanksi AR. Netizen sampel 13 dan 14 menunjukkan tidak peduli terhadap wasit tersebut. Hal ini terlihat dari doa netizen supaya wasit dan keturunannya buta, impoten, stres, dan bunuh diri. Netizen memberi doa yang merugikan wasit tanpa memperhatiakn perbedaan kualitas penglihatan antara menonton pertandingan melalui teknologi canggih (rekaman video di televisi) dan menonton dengan menggunakan mata wasit sendiri (tanpa disertai bantuan teknologi).

\section{b. Faktor yang Mempengaruhi Perilaku Netizen dalam Berkomentar}

1) Pengetahuan Moral

Menurut Lickona (1997), setelah pengetahuan moral yaitu perasaan moral, kemudian tindakan moral. Dengan demikian, pengetahuan moral netizen dalam menggunakan media sosial dapat mempengaruhi tindakannya saat memberi komentar suatu unggahan. 
Di media sosial, berkumpul netizen yang berasal dari berbagai lingkungan sosial sehingga bentuk komentarnya pun beragam. Ada komentar yang sesuai dengan standar moral dan ada juga yang kurang sesuai.

Netizen yang berasal dari lingkungan sosial edukatif akan berbeda dengan netizen yang berasal dari lingkungan sosial sebaliknya. Hidup di lingkungan sosial edukatif akan memberi pemahaman tentang pentingnya menjadi makhluk sosial yang bertindak berdasarkan nilai dan norma. Apabila seseorang tidak mendapat pendidikan dan hidup di lingkungan yang jauh dari nilai-nilai kebajikan, maka ia akan kesulitan untuk mengenal pengetahuan moralnya sebagai makhluk sosial. Saat dihadapkan dengan berbagai situasi di media sosial, ia menjadi kurang mampu dalam memilih tindakan baik dan tepat dalam merespon situasi.

2) Kebutuhan untuk Diakui

Manusia memiliki beragam kebutuhan hidup seperti kebutuhan fisiologis, rasa aman, rasa memiliki dan cinta, penghargaan, serta aktualisasi diri (Maslow, dalam Friedman \& Schustack, 2008). Netizen yang meluangkan waktu di tengah beragam aktivitasnya untuk mengamati, memberi komentar, dan berdebat dapat dikatakan bahwa ia memiliki kebutuhan untuk dihargai atau diakui keberadaannya, baik itu pengakuan atas pandangan pribadinya maupun pengakuan tingkat kekuatan opini netizen terhadap perilaku anggota sosial di dunia maya.

3) Kesiapan Mental Menerima Ruang Publik Baru

Media sosial adalah ruang publik baru bagi masyarakat dalam melakukan interaksi. Ruang publik baru ini memberikan kebebasan berperilaku. Terkait hal tadi, Barnes (dalam Hafiz, 2016) mengungkapkan bahwa di dunia internet terdapat ilusi antara privasi dan ruang publik. Dengan demikian, kebebasan ini akan membuat netizen kurang mampu membedakan perilaku yang boleh dan tidak boleh ditampilkan di ruang publik baru.

4) Karakter Lingkungan Dunia Maya 
Di media sosial, seseorang melakukan interaksi sosial tidak langsung dan dapat menyembunyikan identitas diri seperti nama dan foto. Situasi seperti ini mendorongnya untuk lebih percaya diri mengemukakan pendapat, mempertahankan prinsip diri, dan melawan orang yang bersebrangan dengannya.

Menurut Hakam dan Nurdin (dalam Purwati, 2018) mengungkapkan bahwa nilai pada diri seseorang memiliki tingkatan yang dimulai dari informasi, keyakinan, sikap, nilai, karakter, sampai jati diri. Ketika nilai moral belum sampai ke tahap karakter diri, maka seseorang akan menampilkan perilaku kurang bermoral saat berada di situasi tersebut.

5) Kesetaraan dan Rasa Memiliki Teman

Jika dibandingkan dengan dunia nyata, perbedaan di media sosial antara netizen satu dengan yang lainnya tidak begitu jelas, misalnya dalam membedakan usia dan tingkat pendidikan. Hal ini membuat netizen merasa setara dengan yang lainnya. Selain itu, netizen mudah mengenali orang yang sepaham dan bersebrangan dengannya melalui komentar-komentar netizen lain yang terdapat di kolom komentar media sosial. Ketika seseorang memiliki perasaan setara dan pandangannya sesuai dengan kebanyakan netizen lain, maka dia memiliki keberanian untuk ikut berkomentar. Kesetaraan dan rasa memiliki teman yang sepaham adalah faktor yang membuat seseorang nyaman untuk ikut berinteraksi dan memberi komentar, meskipun komentar tersebut dapat merugikan orang lain. Hal ini berdasarkan sifat otak limbik manusia yang mempunyai peran dalam mempertahankan kelangsungan hidup (Navarro, 2015). Adanya otak ini membuat manusia memiliki sifat alami untuk berada di situasi atau tempat nyaman dan menghindari hal yang dapat merugikan dirinya. Apabila manusia jauh dari nilai-nilai kebajikan, maka ia memiliki keberanian berperilaku sebebas-bebasnya ketika ia berada di situasi yang dianggapnya aman dan nyaman untuk melakukan perilaku tadi. 


\section{Simpulan}

Bahasa yang digunakan netizen dalam berkomentar di akun instagram @pengamatsepakbola adalah bahasa tidak santun. Bahasa tersebut merugikan dan merendahkan orang lain, juga tidak sesuai dengan nilai serta norma yang berlaku di masyarakat. Penggunaan bahasa santun ini dipengaruhi oleh tingkat pengetahuan moral netizen mengenai cara berinteraksi di media sosial, keinginan untuk diakui keberadaannya (pendapat atau pandangan pribadi), rendahnya mental sebagai anggota masyarakat digital dalam menerima perkembangan teknologi yang pesat, kesempatan berperilaku sebebas-bebasnya, keyakinan adanya kesetaraan dan rasa memiliki teman dalam berkomentar di media sosial.

\section{Referensi}

Aziz, M. A. (2018). Netizen Jurnalisme dan Tantangan Dakwah di Media Baru. Islamic Comunication, 3(2), 121-140.

Dari, A. W., Chandra, D. E., \& Sugiyati, S. (2017). Analisis Kesantunan Berbahasa pada Kegiatan Pembelajaran Kelas VIII E Smpn 2 Kota Bengkulu Tahun Ajaran 2016/2017. 10-21.

Friedman, H. S., \& Schustack, M. W. (2008). Kepribadian Teori Klasik dan Riset Modern (3 ed.). Jakarta: Erlangga.

Gunawan, I. (2018). Hubungan Sebab Akibat Ungkapan Pahlawan Tanpa Tanda Jasa terhadap Identitas dan Kesejahteraan Guru di Indonesia. Pedagogia: Jurnal Ilmu Pendidikan, 16(2), 123-130.

Hafiz, S. E. (2016). Moralitas di Internet: Kegagapan akan Ruang Publik Baru. In Psikologi dan Teknologi Informasi (hal. 191-125). Jakarta: Himpunan Psikologi Indonesia.

Inderasari, E., Achsani, F., \& Lestari, B. (2019). Bahasa Sarkasme Netizen dalam Komentar Akun Instragram "Lambe Turah." Semantik, 8(1), 37-49.

Lickona, T. (1997). Educating for character: A comprehensive approach. In The construction of children's character.

Navarro, J. (2015). Cara Cepat Membaca Bahasa Tubuh. Jakarta Selatan: Change. 
Purwati, Indra Gunawan

Pantu, A., \& Luneto, B. (2017). Pendidikan Karakter dan Bahasa. Journal Al-Ulum, 14(1), 153-170.

Purwati. (2018). Analisis Interaksi Simbolik di Sekolah Dasar dalam Membangun Karakter Siswa. UPI.

Rahardi, R. K. (2005). Pragmatik Kesantunan Imperatif Bahasa Indonesia. Jakarta: Erlangga.

Sauri, S. (2017). Kesantunan Berbahasa (Kajian Nilai, Moral, Etika, Akhlak, dan Karakter). Bandung: Royyan Press.

Sudaryanto. (1992). Metode Linguistik. Yogyakarta: Gajah Mada University Press.

Supratman. (2017). Kesantunan Berbahasa Indonesia Santri dalam Pergaulan di Lingkungan Pondok Pesantren Al Bayan Makassar.

Yule, G. (2006). Pragmatik. Yogyakarta: Pustaka Pelajar. 